This is a postprint version of the following published document:

Pacios Lozano, A. R. (1997). ISO 9000 and the total quality management models. Library Management, vol. 18 , no. 3, pp.148-150.

DOI: $\underline{10.1108 / 01435129710166464}$

C Emerald 1997 


\section{ISO 9000 and the total quality management models}

\section{Ana Reyes Pacios Lozano}

The author

Ana Reyes Pacios Lozano is Profesora Titular de Univer-sidad, Departamento de Biblioteconomia y Documentacion, Universidad Carlos III, Madrid, Spain.

\section{Abstract}

Establishes the most outstanding differences between the ISO 9000 norms and total quality management as forms or manners of managing quality used in some information services. Compares two models of total quality: European Foundation for Quality Management and Malcolm Baldrige Awards.

\section{Introduction}

Some units of information attempt to define their quality by projecting a positive answer to the expectations of the customers that constitute its target market. To do this they put emphasis on customer satisfaction and on continuous improvement. In the same way as other organizations, they have considered that quality:

- must always be determined by the customer because it is, in fact, in direct proportion to the use, value and utility that it gives him[1];

- is a relative concept, which constantly changes, since it depends on something so aleatory as the customer's wishes and necessities; and

- bearing in mind the characteristics of the product or service, it also includes the attributes referring to intangible or less visible forms of quality such as those associated with its offering.
Therefore, quality is not only reduced to "what is offered" (the product or service that is supposed to have quality), but also to "how it is offered".

\section{The management of quality}

The inherent characteristics of the services intangibility, inseparability and heterogeneity[2] - show that a fundamental part of quality is associated to their direct offering. But another part depends on a series of actions related to activities developed in organizational units different to the one which is doing the service. That is to say that quality does not appear only in the moment of offering the service but rather affects all the activities of the organization that interact in order to make the service possible and that in the final quality, each previous detail is important. Because of that, more than simply thinking about quality as a punctual act, we should refer to quality management as the whole group of activities that any organization should develop in order to succeed in offering services of quality. This supposes a process of identifying, accepting, satisfying and constantly surpassing the expectations and necessities of all the customers related to the products and services that it offers.

Quality should not be about an independent or specific management, but should be composed of the management and administration of all the processes, decisions, functions and tasks of the organization, at all levels and 
implicating all people, with the necessary setting in practice of the orientation towards the customer on all fronts of the organization; doing the right thing correctly first time in order to meet the objectives[3].

While thinking about that kind of management, it is possible to ask if there is any established form of creating it or an ideal model to follow. The answer is no. There is neither a single model nor a unique solution. Different theorists, specialists and institutions have proposed more or less similar models that offer a series of aspects on which quality management can be based. Total quality management (TQM), as a form or manner of managing quality, has been converted into a new system of administration and management. Also, it is seen as a different form of conceiving day-today work in organizations by taking into account concrete objectives, ratios and data on which to base oneself in order to take decisions and implicate all the personnel. It is intended to satisfy the needs of the customers, doing things right first time. Also, as an answer to the international concern for the improvement of quality in economic relationships, the international standards organization, ISO, has elaborated and published a series of standards - series 9000 - that are meant to encourage the management of quality in any type of organization.

The ISO 9000 standards define the basic elements, which are necessary to acquire and administer under quality criteria. They offer an inventory of aspects, with a fundamentally organizational character, that is supposed to be considered in the activities of managing quality. These standards are focused on the compilation of aspects or elements that should define the management frame, but they are in no way guides on how to do things. They indicate what to do but not how to do it, which is the responsibility of each organization.

Our information units, in the same way as other organizations, have begun to manage quality based on some total quality model or other, for example the European, and also following the ISO 9000 standards. This is entitled "Administration of quality and elements of the system of quality", whose part 2 is specifically dedicated to the services sector[4]. It identifies, as we have already indicated, the most significant aspects that should be kept in mind when, from a conceptual point of view, the development and implementation of a system with these characteristics is desired. Unlike the others, their guidelines are closer to the principles of total quality management.

\section{Main differences between ISO 9000 and total quality}

The fundamental difference between the ISO 9000 standards and total quality is that the latter, as a philosophy of management, has a broader spectrum. The most outstanding characteristics referring to the basic priorities, key factors and principles of action, are as follows.

Contrary to the quality assurance towards which the ISO 9000 standards are directed, total quality searches for excellence[5]. In this sense, the basic priorities of total quality are to achieve customer satisfaction and efficiency, while the ISO 9000 standard is centred only on completing contractual commitments with the customers. In order to guarantee the quality of the product or service offered to the customer, the standards consider that it is necessary to work with raw materials and processes of quality. Based on this they attach great importance to the management of quality in suppliers and in all the manufacturing process including the design and the specifications that the products or services should achieve. Also, they undertake the process of revising the contract or management of orders, since they not only consider it necessary to operate with raw materials and processes of quality, but they should also understand and transmit appropriately what the customer wants, in order to avoid delivering something of quality but different to the product ordered.

The key factors for the success of total quality are the commitment of the managers and the co-operation of all the people that form part of the organization. For ISO 9000, what is fundamental is the rigorous application of procedures and the adequate composition and motivation of personnel.

The foundations or principles of action of total quality are to act on the process of the business, procuring continuous improvement and incorporating the "best practices" of the sector or of leading companies outside the sector. On this point, ISO 9000 limits itself to the productive or service processes and serves also as a base for continuous improvement, understood as the continuous reduction of non-conformities.

In an effort to stress the larger spectrum of total quality with respect to the ISO 9000 standards, we have compared two models of 


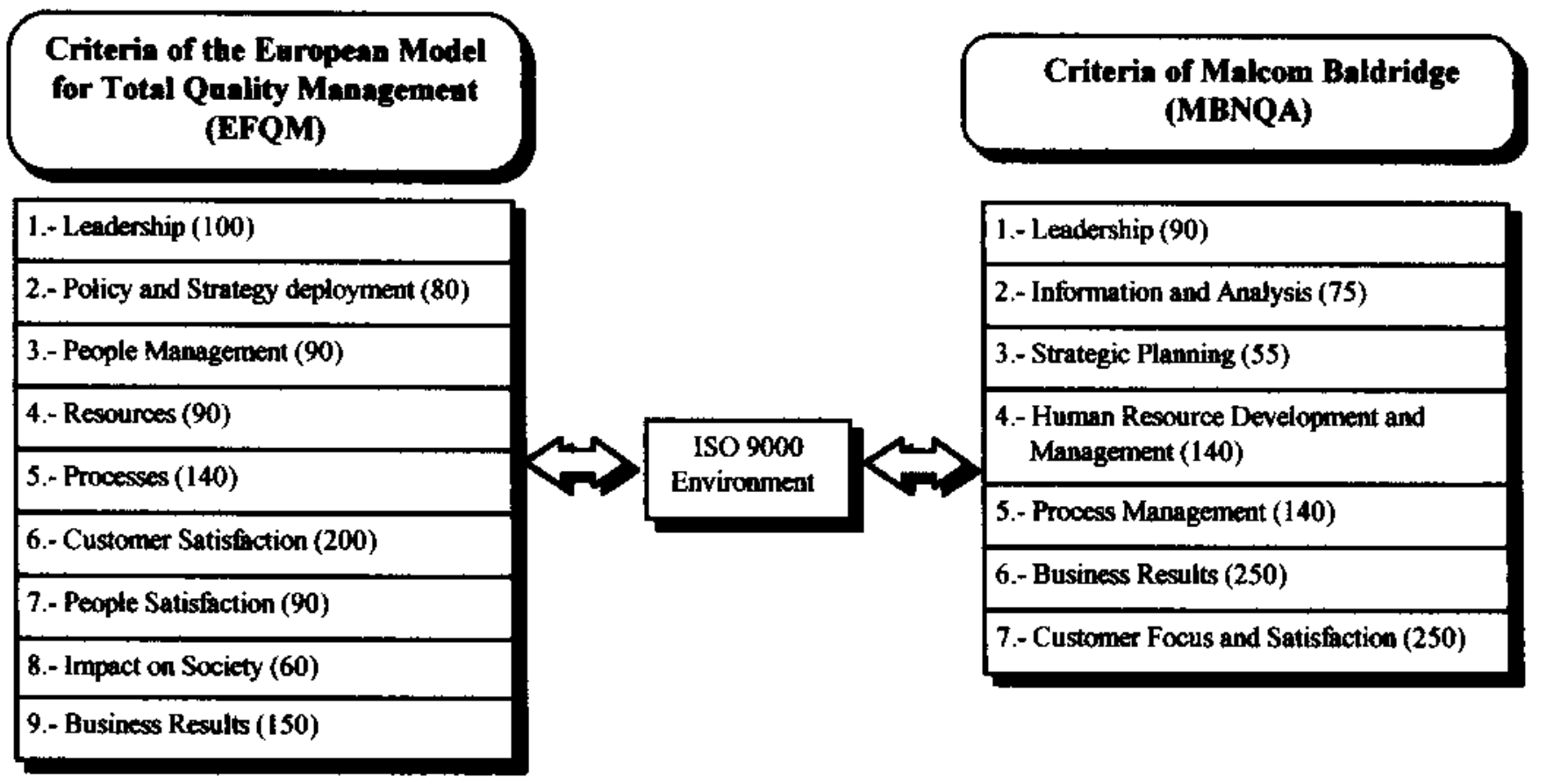

total quality. They correspond to two prestigious awards of the moment: the Malcolm Baldrige Award, in existence in USA from 1987, and the European Award for Quality, given for the first time in 1992. In Figure 1 we show the criteria that are used in both in order to evaluate the progress of an organization towards excellence and the points assigned to each one in the convocation of 1995[6]. The figure indicates the importance that each of the factors has in the global evaluation of the organization out of a total of 1,000 points.

In the European model of quality (EFQM), as used by some information services in Spain in order to carry out the internal diagnoses of quality[7], out of a total of 1,000 points half are assigned to parameters 6 to 9 , related to outputs, and the other half to the criteria 1 to 5 , named agents and which facilitate these outputs. In the Malcom Baldrige awards, only the criteria 6 and 7 , related to output and customer satisfaction, score half of the total. With reference to the ISO 9000 standards, they are centred on point 5 of each model, dedicated in each case to processes. As can be appreciated by the points assigned, they are important but only relatively so, within the criteria of both awards.

\section{Notes and references}

1 Regarding this, the words of Adela d'Alos are significant when commenting on her experience: "From the first moment we had it clear that the quality of the service is the quality that the customer measures and considers." (Disseny y implementació d'un projecte de millora de qualitat en una empresa de servei d informació, Jornades Catalanes de Documentacio, 5es, Barcelona, 1995, p. 164).

2 Lloret, N. y Latorre Zacares, J., ¿Per què implantar un sistema de qualitat segons les normes ISO 9000 en un centre de documentació?, Jornades Catalanes de Documentacio, 5es, Barcelona, 1995, p. 190.

3 Romero, C., Concepto y praxis de la calidad, La calidad en la empresa (II), Círculo de empresarios, Madrid, 1991, p. 155.

4 Senille, A. y Stoll, G., Calidad Total y Normalizacion: ISO 9000. Las Normas Para la Calidad en la Práctica, Ediciones Gestión 2000, Barcelona, 1994, p. 155-68.

5 In the last congress of the European Foundation for the Management of Quality, held in May 1995, a name change was even suggested, and some speakers manifested their favourable opinion of the term "excellency in management".

6 According to the bulletin: Malcom Baldrige National Quality Award: 1995 Award Criteria, October 1994 and The European Prize for Quality: Bulletin of Inscription.

7 Examples are: the central library of the University of Cádiz (Duarte Barrionuevo, M., "Evaluación, TQM y bibliotecas. La calidad total como objetivo estratégico de la gestión bibliotecaria", IV Jornadas españolas de Documentación Automatizada, Gijon, 1994, p. 279-93) and the company of information services DOC6 (D'AlosMoner, A., "Disseny y implementació d'un projecte de millora de qualitat en una empresa de servei d'informacio", 5es. Jornades Catalanes de Documentacio, Barcelona, 1995, p. 163-70 or D'Alos-Moner, A., "Experiencia de calidad en una empresa de servicios de informacion", Jornadas De la teoría a la accion: la Gestion de Calidad en Bibliotecas y Servicios de Documentación. Madrid, 29 y 30 Enero 1996). 
This article has been cited by:

1. Alem Demissie, Weihang Zhu, Daniel Kitaw, Amare Matebu. 2017. Quality assessment and improvement for Ethiopian garment enterprises. Journal of Industrial and Production Engineering 34:6, 450-460.

2. . References 189-204.

3. Valéria Martin Valls, Waldomiro de Castro Santos Vergueiro. 2006. Quality management on information services according to ISO 9000. New Library World 107:11/12, 523-537.

4. Alira Srdoc, Alojzij Sluga, Ivan Bratko. 2005. A quality management model based on the "deep quality concept". International Journal of Quality \& Reliability Management 22:3, 278-302.

5. Hongyi Sun, Sapphire Li, Karis Ho, Frank Gertsen, Poul Hansen, Jan Frick. 2004. The trajectory of implementing ISO 9000 standards versus total quality management in Western Europe. International Journal of Quality \& Reliability Management $21: 2,131-153$.

6. Sang-Bok Lee. 2002. A Study on the Application of Quality Certification System in Library Services. Journal of the Korean Society for Library and Information Science 36:1, 211-231.

7. M.T. Hides, Z. Irani, I. Polychronakis, J.M. Sharp. 2000. Facilitating total quality through effective project management. International Journal of Quality \& Reliability Management 17:4/5, 407-422. 